BHUMI: Jurnal Agraria dan Pertanahan

Received: October 7, 2021; Reviewed: November 4, 2021; Accepted: November 29, 2021.

To cite this article: Herningtyas, W. (2021). Conflict of Palm Oil Companies with Indigenious People and Forest Surrounding Society, Bhumi, Jurnal Agraria dan Pertanahan, 7 (2), 199-209.

DOI: 10.31292/bhumi.v7i2.504

Copyright: (일 Wieke Herningtyas. All articles published in Jurnal Bhumi are licensed under a Creative Commons Attribution-ShareAlike 4.o International license.

Research Article

\title{
CONFLICT OF PALM OIL COMPANIES WITH INDIGENOUS PEOPLE AND FOREST SURROUNDING SOCIETY
}

\author{
Wieke Herningtyas ${ }^{{ }^{*}}$ \\ 'Balai Penelitian dan Pengembangan Lingkungan Hidup dan Kehutanan Kupang \\ Jl. Alfons Nisnoni No. 7 (Belakang), Airnona, Kupang, Kupang \\ *Correspondence E-mail: wiekehtyas@gmail.com
}

\begin{abstract}
Oil palm was one of profitable industrial crops. Oil palm high demand in industries encouraged new plantation field opening as oil palm plantation by means of forest conversion method. From land acquisition to oil palm plantation management, tenurial conflict often occurs. This article aimed to map some existing researches concerning conflict of palm oil companies with indigenous and surrounding forest community in Indonesia. This article uses systematic review method by using conflict-related keywords as assisting tool in filtering the data in order to acquire matching articles. Conflict of palm oil companies with indigenous people and surrounding forest community was distributed into four types. Type 1 was the conflict related to land acquisition and HGU permit. Type 2 was the conflict related to plasma plantation development and land compensation which would be used for plasma plantation. Type 3 was the conflict related to Broken Promises and Unfulfilled CSR Commitment. Type 4 was the conflict which occurred during plasma plantation management by cooperatives and companies for oil palm production (TBS and CPO).
\end{abstract}

Keywords: conflict, plantation, palm oil, indigenous people, people surrounding society

Intisari : Kelapa sawit merupakan salah satu produk tanaman industri yang menguntungkan. Tingginya permintaan kelapa sawit oleh pasar industri mendorong pembukaan lahan perkebunan baru untuk perkebunan kelapa sawit melalui konversi hutan. Konversi lahan sering terjadi konflik tenurial. Artikel ini bertujuan untuk memetakan penelitian-penelitian terdahulu mengenai konflik antara perusahaan perkebunan kelapa sawit dengan masyarakat adat/masyarakat sekitar hutan di Indonesia. Penelitian ini menggunakan metode sistematik review dengan menggunakan kata kunci sebagai alat bantu dalam proses penyaringan untuk mendapatkan artikel yang sesuai. Konflik antara perusahaan perkebunan kelapa sawit dengan masyarakat adat/masyarakat sekitar hutan dibagi menjadi empat tipe. Tipe 1 adalah konflik terkait akuisisi lahan dan perizinan HGU. Tipe 2 adalah konflik yang terjadi terkait pengembangan perkebunan plasma dan ganti rugi lahan yang akan digunakan untuk perkebunan plasma. Tipe 3 adalah konflik yang terjadi terkait janji yang tidak ditepati dan komitmen dari CSR yang tidak dipenuhi. Tipe 4 adalah konflik yang terjadi dalam pengelolaan kebun plasma oleh koperasi dan perusahaan untuk menghasilkan kelapa sawit (TBS dan CPO).

Kata Kunci: kelapa sawit, konflik, masyarakat adat, masyarakat sekitar hutan perkebunan 


\section{A. Introduction}

Indonesia is put in $8^{\text {th }}$ rank of countries with large forest area in the world (Morales-Hidalgo et al., 2015). According to statistical data by Ministry of Environment and Forestry (2014), the terrestrial forest in Indonesia has area of $120.981 .305,98$ ha or $62,9 \%$ of Indonesia's total mainland area. This large forest resource is state asset which have to be preserved and carefully managed in order to prevent forest damage.

This large forest area invites many stakeholders with various responsibilities in forest area management. In the range of 2010-2015, Indonesia had the highest cases of forest area decrease which was 684.00o ha per year (Keenan et al., 2015). According to Morales-Hidalgo et al. (2015), in the period of 2000-2015, Indonesia had primary forest loss of 3,4 million hectare, which is the fourth biggest deforestation after Papua New Guinea, Brazil and Gabon. This is furthermore evidenced in Margono et al. (2014), in the range of 2000-2012 Indonesia lost primary forest with the total of 6,02 million ha. Oil palm plantations were the single largest driver of deforestation accounting for $23 \%$ of national deforestation (Austin et al., 2019).

Oil palm is one of industrial crops with massive and profitable production. Indonesia's palm oil production in 2008 was estimated to reach 42,86 million tons from 14,31 million ha of oil palm plantation area (Kementan, 2018). In 2018, the palm oil production contributed US $\$ 18,23$ billion from export income (Kemendag, 2019). Indonesia is the largest exporter of CPO in the world, sharing global market dominance with Malaysia (Khatiwada et al., 2021).

The high demand of oil palm industrial market causes new field opening in the forest for oil palm plantation purpose. More than 5 million hectares of forest area had been converted into oil palm plantation until mid of 2015 (KemenLHK, 2016 in Prabowo et al., 2017). This number is estimated to increase up to more than 20 million until 2020 (Pacheco, 2012). Based on the field status, $47 \%$ of oil palm plantation area was from logged-over (forest areas), which was field status change from forest into oil palm plantation (Erniwati et al., 2017). Research conducted by Prabowo et al. (2017) revealed fact that oil palm plantation may have power to control forest field and convert it into oil palm plantation, in which the field with forest status is allowed to be used as oil palm plantation.

From land acquisition to oil palm plantation management, tenurial conflict related to land control and utilization often occur. In the conflict, indigenous and surrounding forest community tend to be the weakest actors. When indigenous and surrounding forest community experienced the conflict with government's policy, they tend to be the victim of the policy because the government is the actual controller of forest resources (Nanang \& Inoue, 2000).

Oil palm plantation is a sensitive issue related to forestry and agriculture, thereby pros and cons on oil palm plantation related to indigenous and surrounding forest community existence still occur. On 4 April 2017, Report on Palm Oil and Deforestation of Rainforests had been legalized by European parliament, in which states specifically that oil palm plantation issue in Indonesia is influential issue which is related to corruption, child workers, human rights violation, and indigenous people rights elimination issues (European Parliament, 2017).

These issues which contain potentials to be conflict need more concern in order to avoid future conflict which may distract company operations (Sumardjo et al., 2014) and indigenous and surrounding forest community rights. This conflict causes dilemma for the government to define the best decision, because any decision defined by the government is likely to bring impact for the people (Putra et al., 2014). This can be solved by mapping the conflict of oil palm plantation and the impact for indigenous and surrounding forest community in Indonesia. This research aimed to: 
1. Map some research concerning conflict of palm oil companies with indigenous and surrounding forest community in Indonesia

2. Provide information by mapping the conflict causes of oil palm companies with indigenous and surrounding forest community in Indonesia identified from the existing research results.

\section{B. Methods}

This research adopted systematic review used by Lowry et al. (2013); Wahono (2015) and Rahayu (2016). Systematic review is the research method to identify, evaluate, and interpret all relevant research results related to specific research problems, specific topics, or concerning phenomena (Kitchenham, 2004; Siswanto, 2010). Principally, systematic review is the research method which summarizes primary research results to present more comprehensive and balanced facts. Systematic review is useful in synthesizing various relevant research results, so the facts presented to policy makers can be more comprehensive and balanced.

This research uses keywords as the assisting tools during the screening process in order to acquire scientific articles which suited inclusion criteria. According to Lowry et al. (2013); Rahayu (2016), systematic review strengths are: 1 . Able to limit systematic error (bias) by identifying, assessing, and synthesizing all relevant studies, 2. Able to identify whether few or no relevant study existed which required new studies, and 3. Able to compile information in large number and produce more reliable findings to help in decision-making process. Aside from the strengths, this method had the following weaknesses: 1. Not all documents are acquirable (missing paper), 2. Despite the transparent method, there are some things which make it not fully repetitive, 3 . There were subjectivities in defining whether the scientific articles would be included or not during analysis based on defined content and topic.

The literature search strategies were conducted by: focusing on scientific articles relating to conflict or issue of oil palm companies with indigenous people and surrounding forest community. The issues were derived into operational definition using keywords and research location in Indonesia. The scientific articles used in this research involved conference proceedings, journal articles, magistrate thesis and undergraduate thesis. There was no time limit for articles published in this article search. All titles that appeared on google scholar via search keywords would be considered. Article search was carried out on July 18, 2019. Article selection was carried out in three stages. The first article selection was that all article titles that appeared on google scholar were then divided into two parts, namely articles that match search keywords and did not match search keywords. Articles that match search keywords were articles that must have words from the search keywords either in the whole or at least in the title, abstract and keywords. For example, the keyword in the search was 'agrarian conflict', then the selected articles were articles that had the word agrarian conflict in the title or abstract or keywords. The search was focused on Google Scholar using following keywords in Bahasa Indonesia: konflik agraria, konflik kawasan hutan, konflik kehutanan, konflik lahan, konflik perkebunan, konflik sawit, konflik sumberdaya and konflik tenurial as well as the keywords in English: (agrarian conflict, forest area conflict, forestry conflict, land conflict, plantation conflict, oil palm conflict, resources conflict, and tenurial conflict) by adding phrases 'in Indonesia' and 'in Asia' to help in search process. The scientific articles acquired were in English and Indonesian. The second article selection was that the article must appear the word 'palm oil' or 'sawit' in the title, or abstract, or keywords, or mention the name of the company engaged in oil palm plantations. The third selection of articles was the search with English keywords, the article must have the word 'Indonesia' in the title, abstract, or keywords. Then, the data was extracted to study the scientific articles which matched to the research criteria. Data were synthesized by tabulating each keyword, categorizing research location and scientific work scopes, and categorizing field status, land use history, and conflict background in order to find the resolutions for conflict of palm oil companies with indigenous people and forest surrounding society. 


\section{Results and Discussion}

\section{Selected Articles}

The research was conducted on July 2019 by using Google Scholar search engine. From the searching process using defined keywords in Indonesian and English, 47 matching articles were acquired. Those are the ones containing 'sawit' (palm oil) in the title, abstract, and keyword or the ones which mentioned companies concentrating in palm oil plantation. This number was very few since there were still more articles discussing palm oil conflict, especially in the research results of final assignments in the form of undergraduate thesis, magistrate thesis, and dissertation which did not appear in Google Scholar searching results. Most of scientific works of university repositories were not in Google Scholar. However, this research only limited the search using Google Scholar to help in the searching process due to its ability to identify the most relevant result from the articles within.

Table 1. Number of articles based on the keywords in which the matching articles found

\begin{tabular}{llll}
\hline \multicolumn{1}{c}{ Keyword } & $\begin{array}{c}\text { Number of } \\
\text { articles }\end{array}$ & $\begin{array}{c}\text { Matching } \\
\text { articles }\end{array}$ & $\begin{array}{c}\text { Totals of matching } \\
\text { articles }\end{array}$ \\
\hline Konflik Agraria (English: Agrarian Conflict) & 50 & 7 & 1 \\
Konflik Kawasan Hutan (English: Forest Area Conflict) & 55 & 1 & 19 \\
Konflik Kehutanan (English: Forestry Conflict) & 34 & 19 \\
Konflik Lahan (English: Land Conflict) & 76 & 20 \\
Konflik Perkebunan (English: Plantation Conflict) & 36 & 0 \\
Konflik Sawit (English: Oil Palm Conflict) & 73 & 1 \\
Konflik Sumberdaya (English: Resources Conflict) & 25 & 0 \\
Konflik Tenurial (English: Tenurial Conflict) & 19 & 0 \\
Agrarian Conflict & 10 & 0 \\
Forestry Conflict & 7 & 0 \\
Land Conflict & 61 & 3 \\
Plantation Conflict & 37 & 0 \\
Oil palm conflict & 54 & 0 \\
Resources Conflict & 3 & & 47 \\
Tenurial Conflict & & & \\
\hline
\end{tabular}
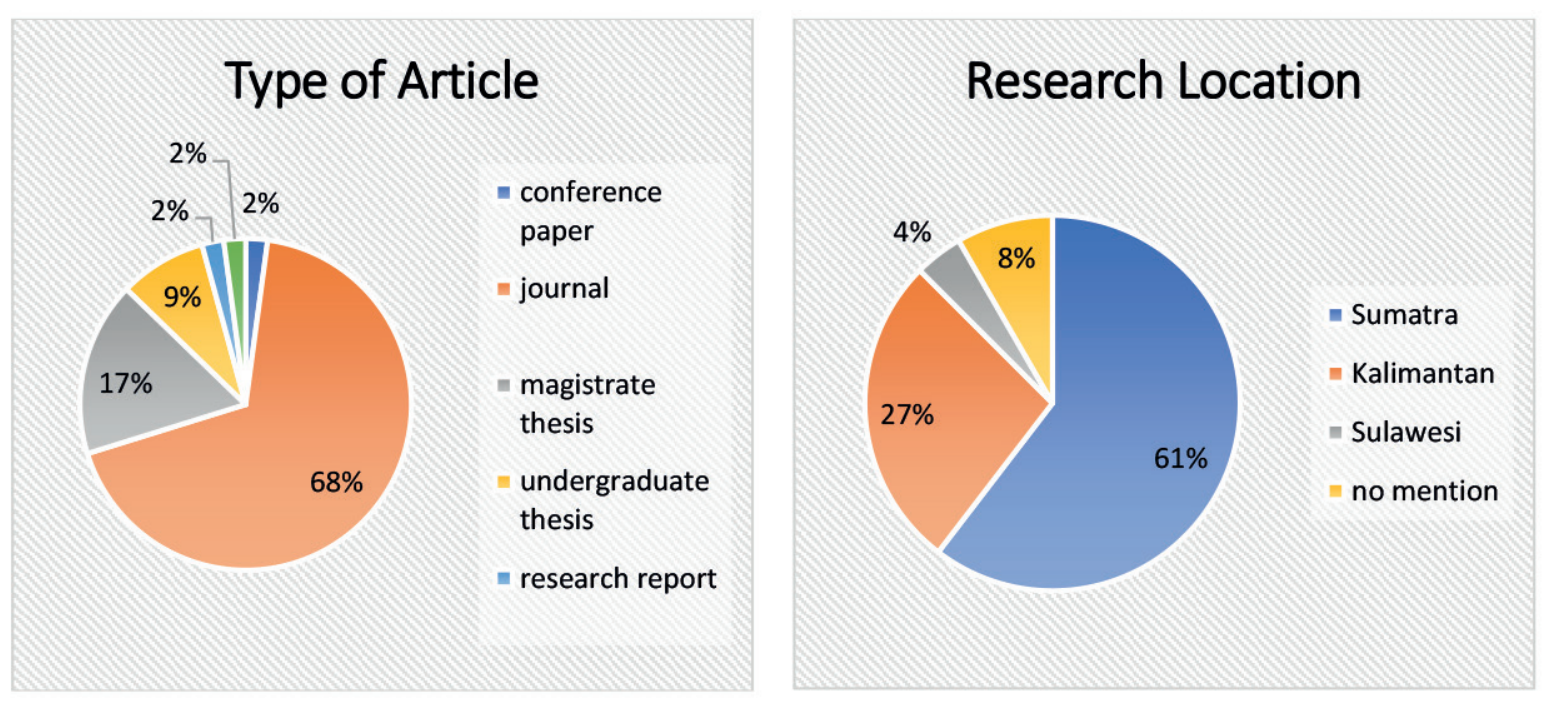

Figure 1. diagram of article results found based on type of article and research location 
From 47 articles found, it can be concluded that the highest number in type of article was journal ( $68 \%$ or 32 journals), followed by magistrate thesis ( $17 \%$ or 8 articles), undergraduate thesis ( $9 \%$ or 4 articles), conference paper ( $1 \%$ or 1 article), conference proceeding ( $1 \%$ or 1 article), and research report ( $1 \%$ or 1 article). While based on research location, most of the research locations were in Sumatra Island ( $62 \%$ or 29 articles), followed by Kalimantan ( $28 \%$ or 13 articles), Sulawesi ( $6 \%$ or 2 articles) and $4 \%$ or 2 articles did not mention the research location. Of the 47 selected articles, no research locations were found on other islands such as Papua. Although the first selection search found articles located in Papua and related to oil palm, for example, Lumintan (2012). But, this study did not include the article in the selected article because it was not included in the 3 stages of selection as described in the research method.

\section{Type Mapping in Oil Palm Plantation Conflict}

In order to easily identify issues in the oil palm plantation, the type mapping in oil palm plantation conflict were divided into four types. Type 1 was the stage where problems occur in land acquisition and HGU licensing. Type 2 was the type when the conflict occurred during plasma plantation construction and the related land compensation. Type 3 was the type when Broken Promises and Unfulfilled CSR Commitment-related conflict occurred. Type 4 was the type when plasma plantation was operated by cooperatives and companies along with the issues related to oil palm production in case of Fresh Fruit Bunch/Tandan Buah Segar (TBS) and Crude Palm Oil (CPO).

Table 2. Number of Articles and Their Relation with the Conflict Type

\begin{tabular}{l|l|l}
\hline No & \multicolumn{1}{|c}{ Conflict Type } & \multicolumn{1}{|c}{ Number of Articles Found } \\
\hline 1 & Type 1 (land acquisition and HGU/Right to Cultivate) & 33 \\
\hline 2 & Type 2 (Plasma plantation and land compensation) & 13 \\
\hline 3 & Type 3 (Broken Promises and Unfulfilled CSR Commitment) & 18 \\
\hline 4 & Type 4 (the production of CPO and TBS) & 11 \\
\hline
\end{tabular}

In the Table 2, from all 47 articles previously mentioned, the articles were classified based on the conflict types. From the classification process based on the types of conflict, the 33 articles were classified in type 1 was from land acquisition to HGU, 13 articles mentioned cases which reached the type of plasma plantation and land compensation, 18 articles showed problems which occurred during Broken Promises and Unfulfilled CSR Commitment process and 11 articles described cases in the profit sharing of CPO and TBS production. Table 3, 4, 5, and 6 are the concluding tables of each type.

Table 3. Summary of the Problems in Type 1

\begin{tabular}{|c|c|}
\hline \multicolumn{2}{|r|}{ Type 1 (Land acquisition and HGU/Right to Cultivate) } \\
\hline 1 & Overlapping area \\
\hline 2 & The company lied by claiming the land based on the HGU, even though the HGU had not yet been issued by BPN \\
\hline 3 & $\begin{array}{l}\text { Abandoned land with overlapping land legality between the company that owns the HGU and the community that } \\
\text { had proof of the legality of the land. }\end{array}$ \\
\hline 4 & The company planted oil palm beyond the boundaries of the area, on community land \\
\hline 5 & The area referred to by the community as their ulayat land was included in the HGU \\
\hline 6 & The empty lot/land belonging to the locals had been taken over by the company resulted in job loss for the locals \\
\hline 7 & The obligation of releasing of the agricultural land, housing and briars for the indigenous people had not been done \\
\hline 8 & Most of the HGU had been used by the community as their agricultural land \\
\hline 9 & The land compensation was insufficient \\
\hline
\end{tabular}

The problems in type 1 started with the land acquisition by the company. The Land acquisition had been carried out since the company first obtained a location permit from the local government and the 
company had not yet obtained an HGU from the BPN (National Land Agency). The long temporal Right to Cultivate permit also supported the company to take corruptive-action such as grabbing the locals' land with false reason that they had already obtained the Right to Cultivate. In type one, the problem which frequently occurred were the overlapping land. Some of the articles analyzed in this research discussed the overlapping land cases. The overlapping land cases could happen due to unprocedural legal permit had been done to obtain Right to Cultivate. Overlapping land also caused the locals lost their farming jobs whereas the rules and the legal procedural of the Right to Cultivate, companies had legal duties to compensate the agricultural land, housing and briars to the local people but it had not been done. The fact was, when the local people picked the forest crops to fulfill their daily needs, the company would accuse them of stealing. To reduce problems in the struggle for land between the company and the community, then a regional boundary agreement was made. But, the company planted beyond the boundaries of the area, on community land. In abandoned land conflicts, there was overlapping land legality between companies that had HGU and the community that had legal evidence in the form: Land Ownership Title/Sertifikat Hak Milik (SHM), Certificate of Land Ownership/Surat Keterangan Tanah (SKT), Certificate of Land Cultivate/Surat Keterangan Tanah Garapan (SKTG) and also the solid confirmation of the farmers'asscociation and land and building tax payment note of the land. Another solution to land conflicts was land compensation, but compensation for agricultural land was often not worth in price.

Table 4. Summary of the Problems in Type 2

\begin{tabular}{l|l}
\hline \multicolumn{2}{c}{ Type 2 (Plasma plantation and land compensation) } \\
\hline $\mathbf{1}$ & The construction of plasma plantation had not been done \\
\hline $\mathbf{2}$ & The plasma plantation location was outside the location of the farmers' cooperatives \\
\hline 3 & The location intended to be the plasma plantations was controlled by the locals \\
\hline 4 & The soil in the location of the planned plasma plantation were less fertile \\
\hline
\end{tabular}

The construction of the plasma considered to be the obligation of the company after they obtained their Right to Cultivate. But the plasma plantation construction often led to several problems and consequently postponed the development. Another problem was in determining the plasma plantation location, plasma plantation location had become the burning issue between the locals and the companies. The locals demanded that the plasma plantation supposed to be inside of the companies' land, whereas the companies wanted to develop it in locals' land. The other problem was the companies decided the plasma plantation location without communicating with the locals, but the land had been already controlled by the locals, or in other case the plasma plantation located beyond control of the village farmers' cooperatives, it caused the access difficulties for the locals. Other problem also the lack of feasibility survey for the land where plasma plantation would be located, it caused the incorrect choice of land, mostly hardly productive land due to its low fertility.

Table 5 Summary of the Problems in Type 3

\begin{tabular}{l|l}
\hline \multicolumn{1}{c}{ Type 3 (Broken Promises and Unfulfilled CSR Commitment) } \\
\hline $\mathbf{1}$ & The company employed non-locals \\
\hline $\mathbf{2}$ & The company had broken the agreement of the locals employment \\
\hline 3 & $\begin{array}{l}\text { The jobs based on man power were replaced by heavy tools/machines which caused the locals lost their job due to the } \\
\text { replacement }\end{array}$ \\
\hline 4 & The partnership agreement between the locals and the companies had been broken by the companies \\
\hline 5 & The MOU had never been executed \\
\hline 6 & The locals were not involved in the partnerships \\
\hline 7 & Companies' CSR had never been distributed
\end{tabular}


MOU agreement was the first phase of the partnership of the companies and the locals, in which these partnerships were expected to increase the locals prosperity. However, in reality most of the companies broke the MOU which had been set such as the companies ceased to employ the locals, taking the non-locals as the employees instead, and the promise of job availability was not fulfilled by the companies. Partnership was an agreement between the companies and the locals but in reality, the decision making was made by companies without involving the locals. After a while, as the partnership between the companies and the locals continued, the companies often neglected the agreement. At first, they employed the locals but companies slowly replaced them with machines. CSR obligation also was not distributed well enough. In other hand, CSR is one of companies' responsibilities in sustainable development for all stakeholders, including the locals.

Table 6. Summary of the Problems in Type 4

\begin{tabular}{l|l}
\hline \multicolumn{1}{l}{ Type 4 (The plasma plantation management and TBS production) } \\
\hline $\mathbf{2}$ & The marketing competition of palm-oil based products \\
\hline 3 & $\begin{array}{l}\text { The companies tend to process palm-oil TBS of their own land so the farmers' TBS had to be kept in their plantation, } \\
\text { causing the palm-oil products quality to decrease }\end{array}$ \\
\hline 4 & $\begin{array}{l}\text { The companies didn't pay for the palm-oil plantation products in cash, but month later, expecting for the } \\
\text { the quantity report of CPO products }\end{array}$ \\
\hline 5 & $\begin{array}{l}\text { The inequality of knowledge and information about the market price between the companies and the plasma } \\
\text { farmers. The companies bought the farmers' products in local currency, while the companies sold the products in } \\
\text { dollar }\end{array}$ \\
\hline 6 & The yield of the plantation was cut to $30 \%$ for paying the farmers debt \\
\hline 7 & The TBS price in the locals was lower than in neighboring plantations \\
\hline 8 & Dissatisfaction in the work system and crops payment \\
\hline 9 & Disparity of crops harvesting quantity. \\
\hline 10 & No information transparency on the profit-sharing mechanism \\
\hline 11 & Lack of coordination between the companies and the village cooperative in managing the plasma plantations \\
\hline 12 & Lack of good-management in the village cooperatives \\
\hline
\end{tabular}

The village cooperatives' role was insignificant in the partnership's agreement between the companies and the farmers/locals/smallholders causing internal management in the village cooperative. The companies then had a bigger/more impact role in partnership and decision making between the two. The companies then put their interest in their own products causing the plasma farmers had to keep their products in their plantation causing low quality products. The yield report had not been transparent enough, causing the farmers to get little information about their products. They only received the reports of their products quantity. It caused the disparity of crops yield in their plantation. The payment also had to wait until the month after, because the company waited for the government's approved price, this made the farmers having difficulties in buying daily needs. Even after waiting for a month, farmers still had to pay $30 \%$ of their yield to pay for their debt to the companies. Farmers also had lack of knowledge and information of their products price, resulting in disparity between the prices. The farmers only had knowledge and information according to the local price, while the companies sell the products into international price, with different currency values, causing the farmers to earn less than expected. The price of the TBS was also found to be in different standard price among the plantations. The price of TBS in one location could be in different range of price although the plantations were still in one tribal affiliated region. This also caused the farmers to feel that the program did not give them any benefit they wanted and made them demand the companies to give their land back.

Of the four types of conflict, it was found that the most conflicts occurred in type 1, namely the problem of land acquisition and HGU issues. The main problem with type 1 was land overlapping 
between the company's area and the lands of the local communities or indigenous peoples. According to Sardjono (1998), the community around the forest is more emphasized on a group of people who for generations have lived in the forest and around the forest and their life and livelihood depends on forest products and or forest land. Meanwhile, according to the Minister of Environment and Forestry Regulation No. P.17/MENLHK/SETJEN/KUM.1/8/2020 concerning private forests and customary forests, they are groups of people who have traditionally lived in certain geographic areas, because of ties to ancestral origins, the existence of a strong relationship with the environment, as well as the existence of a value system that determines economic, political, social and legal institutions. In this study, several selected articles were unable to provide information on whether the research subjects were indigenous peoples or local communities because the terms used were village communities.

In general, conflicts involving indigenous peoples and local communities have different characteristics because indigenous peoples do not have legal evidence in the form of certificates. Customary/ulayat land is the joint ownership of the customary communities, so it cannot be registered in a private name. Recognition of customary/ulayat land is carried out by recording it in the land register and stipulating it in regional regulations. Meanwhile, communities around the forest generally have proof of ownership in the form of a certificate. Low recognition from the government of indigenous peoples is a major factor in land problems, as Qodriyatun (2015) stated that the government regulates indigenous peoples but each ministry has different definitions and policies and cannot always touch all indigenous peoples. As a result of this, one of which has implications for the area permit from the company which is obtained in the form of state forest, it is possible to have a customary forest in the area. Because according to Law No 41/1999 on forestry (before the revision) article 1 stated that customary forest was state forest located in the territory of customary law communities, and article 5 also stated that state forest could be in the form of customary forest.

Various efforts have been made in order to protect the rights of indigenous peoples, one of which is through the Constitutional Court Decision on the case number 35/PUU-X/2012 which decided that customary forests should not be classified as state forests (Hidayat, et al. 2018). Meanwhile, according to Law 41 of 1999, the customary forest was established as long as in reality the customary law communities still exist and their existence and their existence is recognized. The Minister of Forestry Circular No. SE.1/Menhut-II/2013 stated that the Minister of Forestry determines the status of customary forests, as long as the existence of customary law has been stipulated by Regional Regulation. So, in this case, community recognition through local regulation is important considering that the release of customary forests from state forests can only be carried out by the Ministry of Environment and Forestry with the approval of the local government.

The government regulates customary forests technically in more detail through the spatial planning agrarian regulation/head of the BPN No 10 of 2016 concerning the procedure for determining communal rights over lands of indigenous peoples and communities residing in certain areas (Nurhakim, et al. 2018). Important strategies in customary forest management are related to the determination of indigenous peoples, the determination of customary forest boundaries, and the establishment of indigenous people's institutions (Subarudi, 2014). Meanwhile, in the case of abandoned land, referring to government regulation no 40 of 1996 concerning the right to cultivate, the right to use the building, the right to use the land, it is stated that the right to cultivate is abolished because it is neglected so that in this case of this abandoned land, the company should not have the right to the land.

Types of conflict 2, 3, and 4 are conflicts between the company and the community. The company's lack of concern for the welfare of society is the main problem of this type of conflict. A mutually beneficial partnership pattern is the solution to this conflict. Another type of conflict found was the ecological impact of oil palm plantation operations on the communities surrounding the plantation, such as the 
activity of the palm oil industry caused environmental pollution which caused the community's livestock to die (Ikhsanda, 2017); the decline in river water quality, the decrease in the air quality, and the decrease in well water discharge (Ruhiyat et al., 2018).

The weakness of this research is that this research uses a small number of only 47 articles. While there are many other articles that discuss conflicts that occur in the palm oil industry. This is because the keywords used in this systematic review are not many and the selection process uses 3 stages as described in the method.

\section{Conclusions}

The number of the articles selected to review for the purpose of this study, are 47 articles. These articles were considered small in quantity, compared to the real number of the articles discussing the palm oil plantation problems, including undergraduate thesis, magistrate thesis and dissertations which never made available to Google Scholar search engine. Most of the articles showed up in repository were not included in Google Scholar. The conflicts which occurred between the palm oil companies and the locals could be classified into 4 types. The first type is the conflict between land acquisition and the legal permit of Right to Cultivate, type 2 were conflicts in the phase of developing plasma plantations and the payment of land compensation used as the plasma plantations. Type 3 is the conflict between Broken Promises and Unfulfilled CSR Commitment. Type 4 is the conflict occurring relating with the management of the plasma plantations by village cooperative and the companies and the problems occurring in the palm oil production, specifically TBS and CPO. Type 1 conflicts are problems that can be resolved by local government through the recognition of indigenous peoples and their rights, namely the issuance of Regional Regulations. In addition, various evidence of land legality issued by the government must be in harmony with the same map reference so that the land does not overlap. Meanwhile type 2,3, and 4 conflicts are problems that can be resolved between the company and the community through a mutually beneficial partnership pattern.

\section{Bibliography}

Austin, G. K., Schwantes, A., Gu, Y., Kasibhatla, P., S. (2019). What causes deforestation in Indonesia?. Environmental Research Letters, 14(2). https://doi.org/10.1088/1748-9326/aaf6db

Erniwati, Ervizal, A. M. Zuhud, Anas, I., Sunkar, A., Santosa, Y. (2017). Independent smallholder oil palm expansion and its impact on deforestation: case study in Kampar District, Riau Province, Indonesia. Jurnal Manajemen Hutan Tropika, 23(3). https://doi.org/10.7226/jtfm.23.3.119

European Parliament. (2017). P8_TA(2017)oog8 REPORT on palm oil and deforestation of rainforests (2016/2222(INI)) Committee on the Environment, Public Health and Food Safety. https://www. europarl.europa.eu/doceo/document/TA-8-2017-0098_EN.pdf

Hidayat, H., Yogaswara, H., Herawati, T., Blazey, P., Wyatt, S., Howitt, R. (2018). Forest, law, and costumary right in Indonesia: implications of a decision of the Indonesian Constitutional Court in 2012. Asia Pacific Viewpoint, 59 (3), 293-308. https://doi.org/10.1111/apv.12207

Ikhsanda, Z. (2017). Konflik Masyarakat Lokal Versus Perusahaan Sawit di Desa Bajayau Kecamatan Daha Barat Kabupaten Hulu Sungai Selatan Daha Barat Kabupaten Hulu Sungai Selatan (Tesis S2). Universitas Gadjah Mada. Yogyakarta.

Khatiwada, D., Palmen, C., Silveira, S. (2021). Evaluating the palm oil demand in Indonesia: production trends, yields, and emerging issues. Biofuels 12(2), 1-13. https://doi.org/10.108o/17597269.2018.146 1520

Keenan, R. J., Reams, G. A., Achard, F., de Freitas, J. V., Grainger, A., Lindquist, E. (2015). Dynamics of global forest area: results from the FAO global forest resources assessment 2015. Forest Ecology and Management, 352, 9-20. https://doi.org/10.1016/j.foreco.2015.06.014 
Kementerian Lingkungan Hidup dan Kehutanan. (2014). Statistik Kementerian Lingkungan Hidup dan Kehutanan tahun 2014. Kementerian Lingkungan Hidup dan Kehutanan, Jakarta.

Kementerian Pertanian. (2018). Statistik Perkebunan Indonesia 2017-2019 Kelapa Sawit. Direktorat Jenderal Perkebunan Kementerian Pertanian, Jakarta.

Kementerian Perdagangan. (2019). Laporan Kinerja Tahun 2019 Direktorat Jenderal Perdagangan Luar Negeri. Kementerian Perdagangan, Jakarta.

Kitchenham, B. (2004). Procedures for performing systematic reviews. Keele University, Eversleigh, Australia.

Lowry, E., Rollinson, E. J., Laybourn, A. J., Scott, T. E., Aiello, M. E., Gray, S. M., Mickley, J., Gurevitch, J. 2013. Biological invasions: a field synopsis, systematic review, and database of the literature. Ecology and Evolution, 3(1), 182-196. https://doi.org/10.1002/ece3.431

Lumintang, O. (2012). Konflik Tanah di Arso Papua 1980-2002. Paramita, 22(1), 1-130. https://doi. org/10.15294/paramita.v22i1.1845

Margono, B. A., Potapov, P. V., Turubanova, S., Stolle, F., Hansen, M. C. (2014). Primary forest cover loss in Indonesia over 2000-2012. Nature Climate Change, 4, 730-735. https://doi.org/10.1038/ nclimate2277

Morales-Hidalgo, D., Oswalt, S. N., Somanathan, E. (2015). Status and trends in global primary forest, protected areas, and areas designated for conservation of biodiversity from the global forest resources assessment 2015. Forest Ecology and Management, 352, 68-77. https://doi.org/10.1016/j. foreco.2015.06.011

Nanang, M. \& Inoue, M. (2000). Local forest management in Indonesia: a contradiction between national forest policy and reality. International Review for Environmental Strategies, 1 (1), 175 - 191.

Nurhakim, L. I., Rubiati, B., Afriana, A. (2018). Eksistensi sertifikat hak komunal atas tanah masyarakat hukum adat di sektor kehutanan dan perkebunan. Bina Hukum Lingkungan, 3(1). https://doi. org/10.24970/jbhl.v3n1.6

Pacheco, P. (2012). Oil palm in Indonesia linked to trade and investment: implications for forests. Agriculture and rural development learning exchange May 2012. Center for International Forestry Research, Bogor.

Peraturan Menteri Lingkungan Hidup dan Kehutanan Nomor P.17/MENLHK/SETJEN/KUM.1/8/2020 tentang hutan hak dan hutan adat. Kementerian Lingkungan Hidup dan Kehutanan. Jakarta.

Peraturan Pemerintah No. 40 tahun 1996 tentang hak guna usaha, hak guna bangunan, hak pakai atas tanah.

Prabowo, D., Maryudi, A., Senawi, Imron, M. A. (2017). Conversion of forests into oil palm plantations in West Kalimantan, Indonesia: insights from actors'power and its dynamics. Forest Policy and Economics, 78, 32-39. https://doi.org/10.1016/j.forpol.2017.01.004

Putra, A. D., Sayamar, E., Kausar. (2014). Konflik dan resolusi konflik perkebunan (studi kasus konflik perkebunan antara PT. Perkebunan Nusantara V Sei Kencana dengan masyarakat Desa Senama Nenek Kecamatan Tapung Hulu Kabupaten Kampar). Jom Faperta, 1 (2).

Qodriyatun, S. N. (2015). Pengabaian Negara Atas Hak Hidup Masyarakat Hukum Adat. Info Singkat kesejahteraan Sosial, 7, No. o6/II/P3DI/Maret 2015

Rahayu, I. E. (2016). Systematic review terhadap penelitian pranata dan tata kelola hutan di Indonesia (Tesis S2). Universitas Gadjah Mada. Yogyakarta.

Ruhiyat, A., Sunaryanto, H., Widjono, S. (2018). Upaya Desa Air Napal dalam menguasai kembali lahan yang terlibat konflik agraria dengan PT Bio Nusantara Teknologi (studi kasus di desa Air Napal, Kecamatan Bang Haji, Kabupaten Bengkulu Tengah. Jurnal Sosiologi Nusantara, 4(1). https://doi. org/10.33369/jsn.4.1.20-28 
Sardjono, M.A. (1998). Upaya pemberdayaan masyarakat di sekitar kawasan hutan di Kaltim: analisis krisis implementasi dan perspektif ke depan. Lokakarya Perimbangan Keuangan Pusat-Daerah. Samarinda 21-22 Oktober 1998.

Subarudi, (2014). Kebijakan pengelolaan hutan adat pasca putusan Mahkamah Konstitusi No. 35/ PUU-X/2012: suatu tinjauan kritis. Jurnal Analisis Kebijakan Kehutanan, 11(3), 207-224. https:// doi.org/10.20886/jakk.2014.11.3.207-224

Sumardjo, Riyanto, S., Saleh, A., Dahri, Firmansyah, A. (2014). Tipologi konflik berbasis sumber daya pangan di wilayah perkebunan sawit. Jurnal Ilmu Pertanian Indonesia, 19 (3), 189-196.

Surat Edaran Nomor: SE.1/Menhut-II/2013 tentang putusan Mahkamah Konstitusi Nomor 35/ PUU-X/2012 tanggal 16 mei 2013. Kementerian Lingkungan Hidup dan Kehutanan, Jakarta.

Undang Undang No 41 Tahun 1999 tentang kehutanan. Pemerintah Republik Indonesia. Jakarta.

Wahono, R. S. (2010). A systematic literature review of software defect prediction: research trends, datasets, methods and frameworks. Journal of Software Engineering, 1 (1). 